\title{
手術時手指消毒における速乾性手指消毒㨈の消毒効果の比較検討
}

\author{
中村 忠之 ${ }^{1,4)} \cdot$ 西條 美恵 ${ }^{2)} \cdot$ 田口 実里 ${ }^{3)} \cdot$ 丸茂 健治 ${ }^{4} \cdot$ 柳川 容子4)
}

\section{Comparison of Disinfection Efficacy of Alcoholic Hand Rubbing Preparations (Surgical Hand Antisepsis) Against Bacteria on Hands of Nurses}

Tadashi Nakamura ${ }^{1,4)}$, Mie Saijo ${ }^{2)}$, Misato TaGuchi ${ }^{3)}$, Kenji Marumo ${ }^{4)}$ and Yoko Yanagawa ${ }^{4)}$

1) Department of Medical Safety Control, Japanese Red Cross Society Nagahama Hospital,

2) Department of Nursing, Japanese Red Cross Society IshinomakiHospital,

3) Japanese Red Cross College of Nursing Guraduate School,

4) Department of Microbiology and Immunology, School of Medicine, Showa University

$(2014$ 年 12 月 2 日 受付 $\cdot 2016$ 年 4 月 25 日 受理)

要 旨

我々は, $1.0 \mathrm{w} / \mathrm{v} \%$ 抢よび $0.5 \mathrm{w} / \mathrm{v} \%$ クルヘキシジングルコン酸塩エタノール液 $(1.0 \%$ 抢よび $0.5 \% \mathrm{CHG}-\mathrm{AL})$ における即時効果抢よび持続効果を， $0.2 \mathrm{w} / \mathrm{v} \%$ ベンザルコニウム塩化物エタノー ル液 $(0.2 \% \mathrm{BAC}-\mathrm{AL})$ を対照として, 看護師 41 名を対象にグローブジュース法 (一部改変)にて比 較検討した. $1.0 \% \mathrm{CHG}-\mathrm{AL}$ 群における消毒直後と消毒 3 時間後の細菌数は, $0.2 \% \mathrm{BAC}-\mathrm{AL}$ 群に 比べて有意に減少し即時効果と持続効果は統計学的に優れていた. CHG-AL 群の両濃度よる消毒 後に検出された主な細菌は Bacillus 属およびコアグラーゼ陰性ブドウ球菌 (CNS) であった. CHG$\mathrm{AL}$ 群の両濃度を比較すると, CNS 生残菌数は $1.0 \% \mathrm{CHG}-\mathrm{AL}$ 群で $1 / 170 \sim 1 / 219,0.5 \% \mathrm{CHG}-\mathrm{AL}$ 群では $1 / 513$ と有意に減少し, Bacillus 属は $1.0 \% \mathrm{CHG}-\mathrm{AL}$ 群で $1 / 7$ ～ $1 / 11$ に有意に減少したが， $0.5 \% \mathrm{CHG}-\mathrm{AL}$ 群では減少しなかった. $\mathrm{CHG}-\mathrm{AL}$ 群の両濃度の消毒直後と消毒 3 時間後で, 全分 離細菌数, CNS 菌数は指数減少が有意に認められ $\mathrm{CHG}-\mathrm{AL}$ が強い持続効果を有することを示し た. 以上の結果から，1.0\% CHG-AL 群の消毒効果はBacillus 属の除菌効果を考慮すると $0.5 \%$ CHG-AL 群より優れていると考えられた.

Key words : クロルヘキシジングルコン酸塩エタノール液 $(\mathrm{CHG}-\mathrm{AL})$, 手術時手指消毒, 持続効 果, Bacillus 属, コアグラーゼ陰性ブドウ球菌(CNS)

はじめに

手術時手指消毒は手術部位感染対策において必須項目 であり, 手指常在菌を可能な限り減少させることを目的 とした最も衛生水準の高い手洗いである. その際に使用 する消毒薬は, 手指消毒後の即時効果と共に持続効果が 求められる. 2002 年に Centers for Disease Control and Prevention (CDC) が発表した「医療現場における手指衛 生のガイドライン」では, 低濃度のクロルヘキシジング ルコン酸塩をアルコールベースの製剤に添加することに

1)長浜赤十字病院医療安全推進室, ${ }^{2)}$ 石巻赤十字病院看護部, ${ }^{3)}$ 日本赤十字看護大学大学院, ${ }^{4)}$ 昭和大学医学部微生物学講座
より，アルコール単剤よりも優れた残留活性が得られる と報告し使用が推奖されている1).わが国でも $1.0 \mathrm{w} /$ $\mathrm{v} \%$ 抢よび $0.5 \mathrm{w} / \mathrm{v} \%$ クルヘキシジングルコン酸塩エ タノール液 (以下， $1.0 \% \mathrm{CHG}-\mathrm{AL}$ および $0.5 \% \mathrm{CHG}-$ $\mathrm{AL})$ を使用するようになってきた. しかし，手術時手指 消毒の方法の違いによる消毒効果の報告はあるが $\mathrm{CHG}-$ $\mathrm{AL}$ 濃度の違いによる報告はなく，1.0\% $\mathrm{CHG}-\mathrm{AL}$ およ び $0.5 \% \mathrm{CHG}-\mathrm{AL}$ の手指消毒効果に関する実験的評価 が必要になった。

本研究では $1.0 \% \mathrm{CHG}-\mathrm{AL}$ および $0.5 \% \mathrm{CHG}-\mathrm{AL}$ の 手指消毒効果について, 手術時手指消毒法の 1 方法で あるウォーターレス法を用いて, 手指消毒直後 (即時効 
果) 抢よび手術時手袋交換の目安である消毒 3 時間後 (持続効果) に抢ける手指常在菌を同定し, その生残菌数 を定量法であるグローブジュース法(以下，GJ 法)を一 部改変して測定し, 通常の速乾性擦式手指消毒剂である $0.2 \mathrm{w} / \mathrm{v} \%$ ベンザルコニウム塩化物エタノール液(以下, $0.2 \% \mathrm{BAC}-\mathrm{AL})$ を対照としてその結果を評価した。

\section{データ概要}

本研究で使用したデータは，A 施設で実施された 「手洗いと手指消毒」の演習で得られた結果で, かつ使 用許可を承諾した者のデータである。これらを元に二次 分析を行った.

\section{材料と方法}

\section{1. 試験製剤}

試験製剤は $1.0 \% \mathrm{CHG}-\mathrm{AL}$ および $0.5 \% \mathrm{CHG}-\mathrm{AL}$ (1.0\%抢よび 0.5\%ウエルアップハンドローション®，吉 田製薬侏) と $0.2 \% \mathrm{BAC}-\mathrm{AL}$ (ウエルパス手指消毒液 $0.2 \%{ }^{\circledR ｝ \text { ，丸石製薬侏）を使用した。 }$

\section{2. 対象}

試験実施前に手技説明を受け同意を得た被験者(看護 師 41 名) に対して, 試験群 1.0\%CHG-AL 15 名, 試験 群 0.5\% CHG-AL 15 名, 対照群 $0.2 \% \mathrm{BAC}-\mathrm{AL} 11$ 名の 3 群を無作為に分けて実施した. 被験者には手指に皮膚 損傷がなく, CHG-AL 製剤と BAC-AL 製剤による過 敏症のないことを確認した。

\section{3. 手指消毒法}

手指菌数測定は, 米国食品医薬品局 $(\mathrm{FDA})$ の「医療 用手指消毒薬製品暫定的最終基準」に扔いて推奨してい る GJ 法に準拠し, その一部を改変して手指消毒直前, 直後と手術用手袋着用 3 時間後 (手術時手袋交換の目安 となる時間)の生残菌数 (集落数)を調べた ${ }^{2}$.

消毒前のサンプル採取は, 通常で用いる普通石畧と流 水を用いた手洗いを実施しない状態で, 左手に手術用滅 菌手袋(パウダーフリー, ニトリル製)を着用し, 介助者 が左手袋に滅菌サンプリング液 (精製水 $1,000 \mathrm{ml}$ 中, $\mathrm{Na}_{2} \mathrm{HPO}_{4} 10.1 \mathrm{~g}, \mathrm{KH}_{2} \mathrm{PO}_{4} 0.4 \mathrm{~g}$, Triton X-100 $\left.1 \mathrm{~g}\right) 50$ $\mathrm{mL}$ を注入した. 1 分間良くマッサージしたのち滅菌サ ンプリング液が漏れないように介助者が外し, 減菌サン プリング液を $50 \mathrm{~mL}$ 滅菌チューブ(ファルコン社)に無 菌的に回収しこれを手指消毒直前液とした。したがって 今回の実験ではベースラインの測定は実施せず, 消毒直 前のサンプリング液は個々の被験者の手指常在菌のほか に通過菌も含むものとした．

手指消毒直後抢よび消毒 3 時間後のサンプル採取は, $1.0 \% \mathrm{CHG}-\mathrm{AL}$ 群扔よび $0.5 \% \mathrm{CHG}-\mathrm{AL}$ 群では, 流水と 普通石鹸での手洗い後に未隇菌のペーパータオルで水分 を拭き取り速乾性擦式手指消毒剂による手指消毒(ウ
ォーターレス法)を行い, 手術用滅菌手袋を着用した。 一方 $0.2 \% \mathrm{BAC}-\mathrm{AL}$ 群では流水々普通石喃の手洗いは実 施せず直接，消毒薬を手に取り手指消毒を行った。その 後消毒前のサンプル採取と同様に GJ 法 (一部改変)で左 手よりサンプリング液を採取し即時効果のサンプルとし た。 サンプリング液採取後は, 自然乾燥後に手術用滅菌 手袋を再度着用し，消毒 3 時間後に左手袋より同様に サンプリング液を採取し持続効果のサンプルとした。

\section{4. 菌種の同定法}

各サンプル $0.1 \mathrm{~mL}$ を SCDLP 寒天培地(レシチンと Tween 80 添加トリプトソイ寒天培地; 栄研化学(排)に

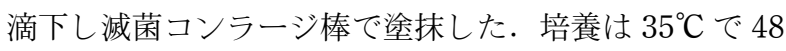
時間好気的に行い形成した集落は形状を観察し，その数 を目視で計数した。

培地上に形成した集落の同定は同一形状の集落から 1 集落を純培養後, 以下の方法で行った．最初にグラム染 色法でグラム陽性桿菌, グラム陽性球菌, グラム陰性桿 菌に分類した.Bacillus 属は肉眼で $\mathrm{R}$ 型集落を確認後, グラム染色で有芽胞グラム陽性桿菌であることを観察し 同定した。Staphylococcus 属と Micrococcus 属は S 型集 落からグラム染色でグラム陽性球菌であることを観察 し，次にブドウ糖の嫌気的分解の有無 (OF テスト)を調 べて同定した。さらに前者と同定された場合， Staphylococcus aureus とコアグラーゼ陰性ブドウ球菌 (coagulase-negative staphylococci，以下, CNS)の鑑別 は，遊離型コアグラーゼ試験抢よび膜結合型コアグラー ゼ試験 (栄研化学( $\left(⿰_{1}\right)$ ), プロテイン $\mathrm{A}$ 検出を $\mathrm{F}$-スタフィ ロ(デンカ生研秼)を用いて行った.グラム陰性桿菌は, TSI 寒天培地 (栄研化学秼) でのブドウ糖発酵能の観察 からブドウ糖非発酵と発酵を鑑別した，真菌は酵母状真 菌が S 型集落, 菌系状真菌がモール状集落をグラム染 色した形態を観察して同定した.

\section{5. 分析方法 \\ 1）各試験群の手指消毒効果の比較}

取得データの分析は, “即時効果あり”または “持続 効果あり”の消毒効果判定が目視で集落が全く観察され ない場合とし，これに対し，“効果なし”は 1 集落以上 観察された場合と便宜的にした (集落検出限界値 $5 \times 10^{2}$ $\mathrm{cfu} / \mathrm{hand}$ ).これらの統計解析は, 標本数が少ない時に 用いる Fisher's exact test (Microsoft Excel 2010)で行 った.

\section{2）各試験群の手指消毒時の細菌生残菌数}

集落数から算出された細菌数は常用対数で表し, 消毒直 後と消毒 3 時間後の効果判定には指数減少值 ( RF : reduction factors $=\log _{10}$ [消毒前菌数/消毒後菌数], mean $\pm \mathrm{SD})$ を算出した。統計解析は Student's $t$ test (Microsoft Excel 2010)で行った. 


\section{6. 倫理的配慮}

本研究を実施するにあたり, 日本赤十字看護大学研究 倫理審査委員会の承認後 $(2012-55)$, 被験者から同意を 得た上で分析を開始した.

\section{結果}

1. 各試験群の手指消毒効果の比較

各試験群の消毒効果の比較成績を表 1 に示した。 $1.0 \% \mathrm{CHG}-\mathrm{AL}$ 群および $0.5 \% \mathrm{CHG}-\mathrm{AL}$ 群の手指消毒直 a. 消毒直後

\section{表 1 各試験群の手指消毒効果の比較}

\begin{tabular}{ccrc}
\hline 試験群 & $\begin{array}{c}\text { 効果ありの人数効果な験者数 } \\
\text { /被験者数 }\end{array}$ & $\begin{array}{c}\text { Fisher's } \\
\text { exact test* }\end{array}$ \\
\hline $1.0 \% C H G-A L$ & $9 / 15(60 \%)$ & $6 / 15(40 \%)$ & \\
$0.5 \% C H G-A L^{2}$ & $6 / 15(40 \%)$ & $9 / 15(60 \%)$ & $p=0.466$ \\
\hline $1.0 \% C H G-A L$ & $9 / 15(60 \%)$ & $6 / 15(40 \%)$ & $p=0.0143$ \\
$0.2 \% B A C-A L^{3}$ & $1 / 11(9 \%)$ & $10 / 11(91 \%)$ & \\
\hline $0.5 \% C H G-A L$ & $6 / 15(40 \%)$ & $9 / 15(60 \%)$ & $p=0.178$ \\
$0.2 \% B A C-A L$ & $1 / 11(9 \%)$ & $10 / 11(91 \%)$ & \\
\hline
\end{tabular}

b. 消毒 3 時間後間後

\begin{tabular}{crrr}
\hline 試験群 & $\begin{array}{c}\text { 効果ありの人数被験者数 } \\
\text { 效果な験者数 }\end{array}$ & $\begin{array}{c}\text { Fisher's } \\
\text { exact test* }\end{array}$ \\
\hline $1.0 \% \mathrm{CHG}-\mathrm{AL}$ & $10 / 15(67 \%)$ & $5 / 15(33 \%)$ & \\
$0.5 \% \mathrm{CHG}-\mathrm{AL}$ & $7 / 15(47 \%)$ & $8 / 15(53 \%)$ & $\mathrm{p}=0.301$ \\
\hline $1.0 \% \mathrm{CHG}-\mathrm{AL}$ & $10 / 15(67 \%)$ & $5 / 15(33 \%)$ & \\
$0.2 \% \mathrm{BAC}-\mathrm{AL}$ & $2 / 11(18 \%)$ & $9 / 11(82 \%)$ & $\mathrm{p}=0.0214$ \\
\hline $0.5 \% \mathrm{CHG}-\mathrm{AL}$ & $7 / 15(47 \%)$ & $8 / 15(53 \%)$ & $\mathrm{p}=0.216$ \\
$0.2 \% \mathrm{BAC}-\mathrm{AL}$ & $2 / 11(18 \%)$ & $9 / 11(82 \%)$ & \\
\hline
\end{tabular}

$* \mathrm{p}<0.05$ で有意差有り

$11.0 \mathrm{w} / \mathrm{v} \%$ クロルヘキシジングルコン酸エタノール液

$20.5 \mathrm{w} / \mathrm{v} \%$ クロルヘキシジングルコン酸塩エタノール液

${ }^{3} 0.2 \mathrm{w} / \mathrm{v} \%$ ベンザルコニウム塩化物エタノール液
後の「効果あり」は，各々 15 名中 9 名 $(60 \%)$ 抢よび 6 名 $(40 \%)$, 消毒 3 時間後の「効果あり」は，各々 15 名 中 10 名 $(67 \%)$ 抢よび 7 名 $(47 \%)$ であった。しかし， CHG-AL の濃度の違いによる手指消毒効果に有意差は なかった． $1.0 \% \mathrm{CHG}-\mathrm{AL}$ 群の手指消毒直後と消毒 3 時 間後の消毒効果は，0.2\% BAC-AL 群に対して有意差が 認められた。一方 $0.5 \% \mathrm{CHG}-\mathrm{AL}$ 群の手指消毒直後と 消毒 3 時間後の消毒効果は, $0.2 \% \mathrm{BAC}-\mathrm{AL}$ 群に対して 有意差は認められなかった。

\section{2. 各試験群の手指消毒時に細菌と真菌が生残した被 験者数}

各試験群の手指消毒直後と消毒 3 時間後に生残した 細菌と真菌の種類, さらにこれらの細菌が分離された被 験者数を表 2 に示した。 $0.2 \% \mathrm{BAC}-\mathrm{AL}$ 群は，手指消毒 直前に検出された CNS と Bacillus 属が手指消毒直後と 消毒 3 時間後で高率 (50\%以上)に検出されたのに対し， CHG-AL 両濃度群では Bacillus 属が高率に生残するの みであった。また $1.0 \% \mathrm{CHG}-\mathrm{AL}$ 群の手指消毒 3 時間 後の CNS 2 例は共に 1 集落の久形成した。.その他少数 ではあるが手指消毒直前にMicrococcus 属, Staphylococcus aureus などが検出されたが，手指消毒後はほとんど 検出されなかった.

\section{3. 各試験群の手指消毒時の細菌生残菌数}

本試験で被験者から分離された手指消毒直前の全細菌 数は $10^{4} \sim 10^{5} \mathrm{cfu} /$ hand で，主に分離された CNS と Bacillus 属に対する手指消毒直前, 直後および消毒 3 時 間後の生残菌数を図 1 に示した.

全細菌は，手指消毒直前に比べ消毒直後と消毒 3 時 間後の生残菌数が $1.0 \% \mathrm{CHG}-\mathrm{AL}$ 群で $1 / 204$ と $1 / 110$ で消毒 3 時間後は有意に減少しなかったが， $0.5 \%$ CHG-AL 群で $1 / 129$ と 1/324, 0.2\%BAC-AL 群で $1 /$ 10 と $1 / 8$ に有意に減少した. CNS は手指消毒直前に比

表 2 手指消毒で生残した細菌および真菌とその被験者数

\begin{tabular}{|c|c|c|c|c|c|c|c|c|c|}
\hline \multirow{2}{*}{ 検出菌 } & \multicolumn{3}{|c|}{ a. $1.0 \% \mathrm{CHG}-\mathrm{AL}^{1}$ 手指消毒 $(n=15)$} & \multicolumn{3}{|c|}{ b. $0.5 \% C H G-A L^{2}$ 手指消毒 $(n=15)$} & \multicolumn{3}{|c|}{ c. $0.2 \% B A C-A L^{3}$ 手指消毒 $(n=11)$} \\
\hline & 直 前 & 直 後 & 3 時間後 & 直 前 & 直 後 & 3 時間後 & 直 前 & 直 後 & 3 時間後 \\
\hline CNS & $\begin{array}{l}13 \text { 名 } \\
(87 \%)\end{array}$ & $\begin{array}{l}0 \text { 名 } \\
(0 \%)\end{array}$ & $\begin{array}{c}2 \text { 名 } \\
(13 \%)\end{array}$ & $\begin{array}{l}12 \text { 名 } \\
(80 \%)\end{array}$ & $\begin{array}{l}0 \text { 名 } \\
(0 \%)\end{array}$ & $\begin{array}{l}0 \text { 名 } \\
(0 \%)\end{array}$ & $\begin{array}{c}11 \text { 名 } \\
(100 \%)\end{array}$ & $\begin{array}{c}6 \text { 名 } \\
(55 \%)\end{array}$ & $\begin{array}{c}7 \text { 名 } \\
(64 \%)\end{array}$ \\
\hline Micrococcus 属 & $\begin{array}{c}5 \text { 名 } \\
(33 \%)\end{array}$ & $\begin{array}{l}0 \text { 名 } \\
(0 \%)\end{array}$ & $\begin{array}{l}0 \text { 名 } \\
(0 \%)\end{array}$ & $\begin{array}{c}4 \text { 名 } \\
(27 \%)\end{array}$ & $\begin{array}{l}0 \text { 名 } \\
(0 \%)\end{array}$ & $\begin{array}{l}0 \text { 名 } \\
(0 \%)\end{array}$ & $\begin{array}{c}3 \text { 名 } \\
(27 \%)\end{array}$ & $\begin{array}{l}1 \text { 名 } \\
(9 \%)\end{array}$ & $\begin{array}{l}0 \text { 名 } \\
(0 \%)\end{array}$ \\
\hline $\begin{array}{l}\text { Staphylococcus } \\
\text { aureus }\end{array}$ & $\begin{array}{l}0 \text { 名 } \\
(0 \%)\end{array}$ & $\begin{array}{l}0 \text { 名 } \\
(0 \%)\end{array}$ & $\begin{array}{l}0 \text { 名 } \\
(0 \%)\end{array}$ & $\begin{array}{c}3 \text { 名 } \\
(20 \%)\end{array}$ & $\begin{array}{l}0 \text { 名 } \\
(0 \%)\end{array}$ & $\begin{array}{l}0 \text { 名 } \\
(0 \%)\end{array}$ & $\begin{array}{l}0 \text { 名 } \\
(0 \%)\end{array}$ & $\begin{array}{l}0 \text { 名 } \\
(0 \%)\end{array}$ & $\begin{array}{l}0 \text { 名 } \\
(0 \%)\end{array}$ \\
\hline Bacillus 属 & $\begin{array}{l}14 \text { 名 } \\
(93 \%)\end{array}$ & $\begin{array}{c}5 \text { 名 } \\
(33 \%)\end{array}$ & $\begin{array}{c}5 \text { 名 } \\
(33 \%)\end{array}$ & $\begin{array}{l}14 \text { 名 } \\
(93 \%)\end{array}$ & $\begin{array}{c}9 \text { 名 } \\
(60 \%)\end{array}$ & $\begin{array}{c}8 \text { 名 } \\
(53 \%)\end{array}$ & $\begin{array}{c}9 \text { 名 } \\
(82 \%)\end{array}$ & $\begin{array}{c}7 \text { 名 } \\
(64 \%)\end{array}$ & $\begin{array}{c}6 \text { 名 } \\
(55 \%)\end{array}$ \\
\hline $\begin{array}{l}\text { ブドウ糖非発酵 } \\
\text { グラム陰性桿菌 }\end{array}$ & $\begin{array}{l}0 \text { 名 } \\
(0 \%)\end{array}$ & $\begin{array}{l}1 \text { 名 } \\
(7 \%)\end{array}$ & $\begin{array}{l}0 \text { 名 } \\
(0 \%)\end{array}$ & $\begin{array}{c}2 \text { 名 } \\
(13 \%)\end{array}$ & $\begin{array}{l}0 \text { 名 } \\
(0 \%)\end{array}$ & $\begin{array}{c}0 \text { 名 } \\
(0 \%)\end{array}$ & $\begin{array}{l}0 \text { 名 } \\
(0 \%)\end{array}$ & $\begin{array}{l}0 \text { 名 } \\
(0 \%)\end{array}$ & $\begin{array}{l}0 \text { 名 } \\
(0 \%)\end{array}$ \\
\hline
\end{tabular}

$11.0 \mathrm{w} / \mathrm{v} \%$ クロルヘキシジングルコン酸エタノール液

$20.5 \mathrm{w} / \mathrm{v} \%$ クロルヘキシジングルコン酸塩エタノール液

${ }^{3} 0.2 \mathrm{w} / \mathrm{v} \%$ ベンザルコニウム塩化物エタノール液 

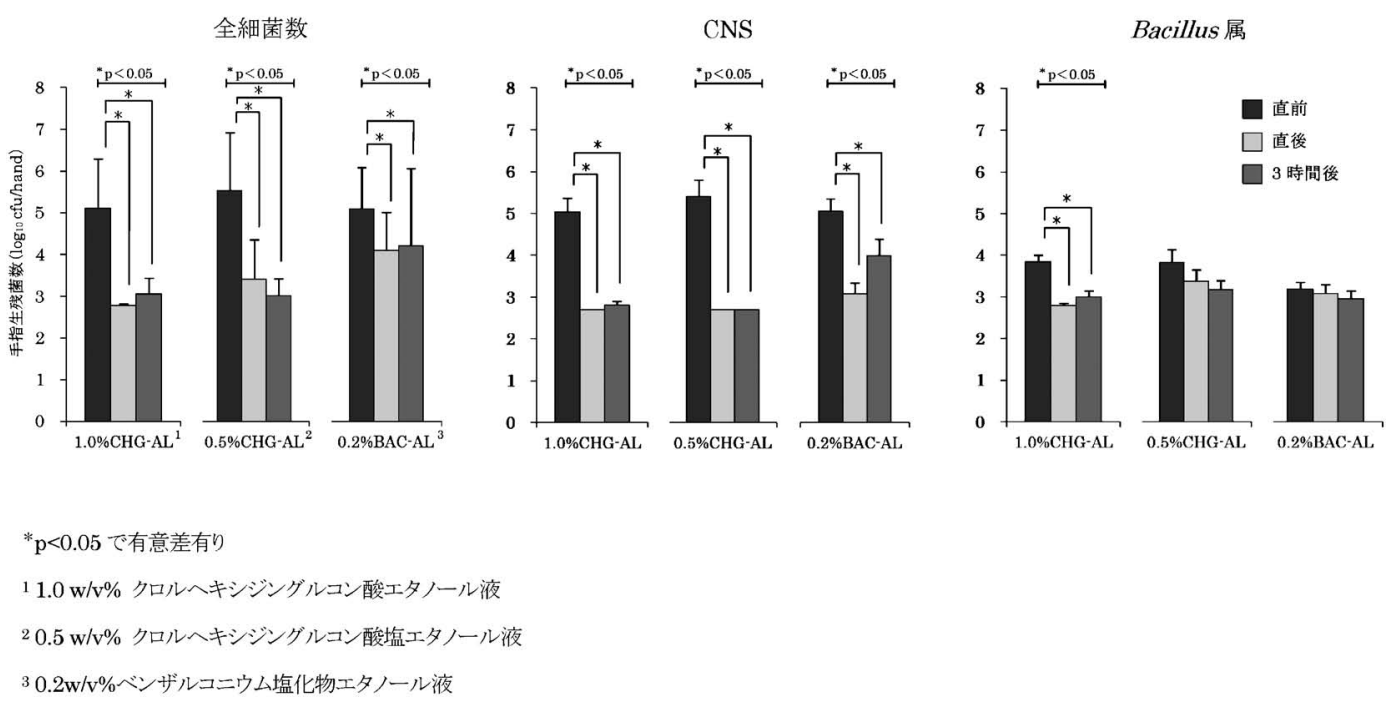

図 1 各試験群の手指消毒直後と 3 時間後の全細菌, CNS およびBacillus 属生残数の比較

べ消毒直後と消毒 3 時間後の生残菌数が， $1.0 \% \mathrm{CHG}^{-}$ $\mathrm{AL}$ 群で $1 / 219$ と $1 / 170,0.5 \% \mathrm{CHG}-\mathrm{AL}$ 群で共に $1 /$ 513, 0.2\%BAC-AL 群で $1 / 91$ と $1 / 11$ に有意に減少し た. Bacillus 属は, $1.0 \% \mathrm{CHG}-\mathrm{AL}$ 群が手指消毒直前に 比べ消毒直後と消毒 3 時間後で $1 / 11$ と $1 / 7$ に有意に減 少したが，0.5\% CHG-AL 群と $0.2 \% \mathrm{BAC}-\mathrm{AL}$ 群は有意 に減少しなかった。したがって $1.0 \% \mathrm{CHG}-\mathrm{AL}$ 群は， $0.2 \% \mathrm{BAC}-\mathrm{AL}$ 群と比べ全細菌, CNS の生残菌数を手 指消毒直後と消毒 3 時間後で有意に低下させたが, 0.5\% CHG-AL 群との比較では有意な低下はみられなか った. 今回の検討では, 各消毒薬に打ける手指消毒直後 と消毒 3 時間後との間の全細菌, CNS および Bacillus 属の RF 值に有意差を認めなかった。 $0.5 \% \mathrm{CHG}-\mathrm{AL}$ 群 は手指消毒直後と消毒 3 時間後で CNS の集落が全く形 成しなかったことから，1.0\% CHG-AL 群と $0.5 \%$ CHG-AL 群の両者間の効果に差がないとした。 以上の 成績から，1.0\% CHG-AL 群および $0.5 \% \mathrm{CHG}-\mathrm{AL}$ 群の 両者は消毒 3 時間後でも消毒効果を持続していた.

\section{考察}

今回の検討で, ウォーターレス法である $1.0 \% \mathrm{CHG}-$ $\mathrm{AL}$ 群および $0.5 \% \mathrm{CHG}-\mathrm{AL}$ 群の手指消毒効果は消毒直 後 (即時効果) で細菌数が有意に減少し, 消毒 3 時間後 (持続効果) でも効果が持続した. 通常消毒前の手指菌数 を測定するには，流水や石畧を用いての手洗いを実施し 手洗い後に検出された菌数を消毒前のベースライン值と する．今回我々はベースライン值ではなく手洗いをしな い, 寸なわち被験者個々の常在菌のほかに通過菌が混入 した手指細菌数を測定し, それらを消毒直後および消毒 3 時間後の細菌数と比較した. よってベースラインを測 定した今村ら 3 のの成績と正確な比較はできないが，被験
者から分離された細菌の種類 (Bacillus 属, CNS, Micrococcus 属など) はほぼ類似していた。また熊谷らは ベースラインを測定した上で $0.2 \% \mathrm{BAC}-\mathrm{AL}$ と $1.0 \%$ CHG-AL の比較を行い， $1.0 \% \mathrm{CHG}-\mathrm{AL}$ は持続殺菌効 果が期待できる手術用手指消毒剂であると報告した4). 我々の結果に掞いても，1.0\% CHG-AL 群の手指消毒効 果は消毒直後の効果を 3 時間持続する結果となった.

今回の検討で培養後の集落同定とその集落数から，手 指消毒直前の全細菌数は $10^{4} \sim 10^{5} \mathrm{cfu} /$ hand であり, 1.0\% CHG-AL 群および 0.5\% CHG-AL 群は全細菌を手 指消毒直後と消毒 3 時間後に $1 / 100$ 以下に有意に減少 させた． $1.0 \% \mathrm{CHG}-\mathrm{AL}$ 群はBacillus 属を手指消毒直後 と消毒 3 時間後でそれぞれ $1 / 11$ と $1 / 7$ に有意に減少さ せたが，0.5\% CHG-AL 群は有意な減少を認めなかっ た.このような Bacillus 属生残に関する $0.5 \% \mathrm{CHG}-\mathrm{AL}$ 群の成績は今村らの報告と同様であった3)。1.0\% $\mathrm{CHG}^{-}$ $\mathrm{AL}$ および $0.5 \% \mathrm{CHG}-\mathrm{AL}$ は共に有芽胞細菌である Bacillus 属には無効の中水準消毒薬である5). Bacillus 属に対するこのような $1.0 \% \mathrm{CHG}-\mathrm{AL}$ 優位性の理由は 不明であるが， CHG は皮膚親和性が高い6)。このため CHG 濃度倍加による手指表面での完全な栄養型状態や 芽胞形成途中 (未熟な芽胞) 状態にあるBacillus 属への消 毒効果の増加が原因であると考えた. 一方, 皮膚常在菌 である CNS は手指消毒直前の細菌数に対し CHG-AL 群の両濃度で $1 / 170 \sim 1 / 513$ の即時効果と持続効果が認 められた。しかし $0.5 \% \mathrm{CHG}-\mathrm{AL}$ 群と比較して $1.0 \%$ $\mathrm{CHG}-\mathrm{AL}$ 群の手指消毒後の生残菌数は有意な減少がみ られなかった. $1.0 \% \mathrm{CHG}-\mathrm{AL}$ 群の消毒 3 時間後に 2 例 で生残がみられ， $0.5 \% \mathrm{CHG}-\mathrm{AL}$ 群の生残なしと矛盾が みられたが， 2 例における生残数はともに 1 集落のみで あったことから，GJ 法 (一部改変) 施行中の污染が考え 
られた。手指消毒直後の生残菌数は, CNS では $1.0 \%$ CHG-AL 群(1/219)より $0.5 \%$ CHG-AL 群 $(1 / 513)$ で少 ない結果となったが, CNS を含む全細菌数の手指消毒 直後の比較では $1.0 \% \mathrm{CHG}-\mathrm{AL}$ 群 (1/204) が $0.5 \%$ CHG-AL 群 $(1 / 129)$ より少ない結果であった.このよ うな無芽胞細菌であるCNS, さらにはそれほどの頻度 ではなかった Micrococcus 属などに対する $0.5 \% \mathrm{CHG}-$ $\mathrm{AL}$ 群の優れた手指消毒効果は, 今村らの報告と同様で あった ${ }^{3)}$. 西原らはカテーテル関連血流感染予防に向け た皮膚消毒の研究で菌種別消毒効果の言及がなかったも のの, CHG-AL 両濃度間に微生物学的薬効に統計学的 有意差がないとしており7), 今回の結果を反映させる成 績であった。

ウォーターレス法による手指消毒は簡易性や費用対効 果の観点から, 今後さらに増加することが考えられ る7). 今回の結果から, 手術時手指消毒のような長時間 持続効果が要求される場合, Bacillus 属の污染を考慮す

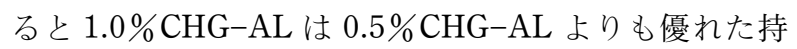
続殺菌効果が期待できると考えられた.

謝 辞 : 本研究に抢いて多大なるご指導とご協力を頂いた昭和 大学医学部微生物学教室教授田中和生先生, 並びに日赤看護大 学看護管理学教授鶴田惠子先生, 被験者としてご協力頂きまし た皆様に深謝致します。

利益相反自己申告：申告すべきものなし．

\section{文献}

1) Boyce JM, Pittet D: CDC guideline for hand hygiene in health-care settings. MMWR Recomm Rep 2002;
51( $\mathrm{rr} 16): 1-44$.

2) Food and Drug Administration: Tentative final monograph for health-care antiseptic drug products; Proposed rules: Federal Register 1994; 59: 31401-52.

3）今村豊, 山下葉子, 因幡美津子, 石橋和重 : $0.5 \mathrm{w} /$ v\%グルコン酸クロルヘキシジン含有エタノール製剤 の手指消毒効果の検討. 環境感染 2007; 22(1): 28-32.

4）熊谷あゆ美, 平内美雪, 和田祐爾, 馬場尚志, 飯沼由 嗣 : $1.0 \mathrm{w} / \mathrm{v} \%$ クロルヘキシジングルコン酸塩含有エタ ノール製剤を用いたウォーターレス手術時手指消毒の 効果〜ツーステージ法との比較．環境感染誌 2012 ; $27(6): 375-9$.

5) 吉田真一, 柳 雄介, 吉開泰信 : 戸田新細菌学 (34 版). 東京. 南山堂. 2013. p.236-44.

6) Larson EL: APIC guidelines for infection control practice, guideline for use of topical antimicrobial agents. Am J Infect Control 1988; 16: 253-66.

7）西原 豊, 梶浦 工, 横田勝弘, 小林寛伊, 菅原えり さ，大久保憲 : カテーテル関連血流感染予防に向けた 皮膚消毒薬としての $1 \mathrm{w} / \mathrm{v} \%$ クルルキシジン $(\mathrm{CHG})$ エタノールの有効性と安全性. 環境感染誌 2013; 28(3): 132-7.

8）白杵尚志，宮脇有紀：2010 年の国内に打ける術前手指 消毒法の実態調査. 手術医学 2011; 32(4): 317-22.

9）深田民人：手術時手洗い法に対するラビング法とスク ラビング法による手術部位感染発生率の比較. 日外感 染症会誌 2006 ; 3(4): 515-9.

10）中居 肇，吉田泰憲，澤田とも子：0.5 w/v\%クロルヘ キシジングルコン酸塩含有エタノール製剤を用いたウ オーターレス法の手術時手指消毒としての評価. 環境 感染誌 2009; 24(5): 342-6.

11）中川博雄, 松田淳一, 桝原克紀, 北原隆志, 佐々木 均： $0.5 \mathrm{w} / \mathrm{v} \%$ グルコン酸クロルヘキシジンおよび $0.2 \mathrm{w} / \mathrm{v} \%$ 塩化ベンザルコニウム含有エタノール液の手 指消毒効果に対する比較検討。環境感染誌 2009; 24(3): 167-9.

〔連絡先 : $=526-0103$ 滋賀県長浜市宮前町 14-7 長浜赤十字病院医療安全推進室 中村忠之 E-mail: cn-t.nakamura@nagahama.jrc.or.jp] 


\title{
Comparison of Disinfection Efficacy of Alcoholic Hand Rubbing Preparations (Surgical Hand Antisepsis) Against Bacteria on Hands of Nurses
}

\author{
Tadashi Nakamura ${ }^{1,4)}$, Mie Saijo ${ }^{2)}$, Misato TaGUCHI ${ }^{3)}$, Kenji Marumo ${ }^{4)}$ and Yoko Yanagawa ${ }^{4)}$ \\ 1) Department of Medical Safety Control, Japanese Red Cross Society Nagahama Hospital, \\ ${ }^{2)}$ Department of Nursing, Japanese Red Cross Society IshinomakiHospital, \\ 3) Japanese Red Cross College of Nursing Guraduate School, \\ 4) Department of Microbiology and Immunology, School of Medicine, Showa University
}

\begin{abstract}
Various rub-in hand disinfectants have been developed for hygienic and surgical hand disinfection. In this study, the immediate and persistent effects of $1.0 \mathrm{w} / \mathrm{v} \%$ and $0.5 \mathrm{w} / \mathrm{v} \%$ chlorhexidine gluconate/ethanol preparations (1.0\% CHG-AL and $0.5 \% \mathrm{CHG}-\mathrm{AL}$, respectively) on the numbers of bacteria on the hands of 41 experienced nurses were investigated using the glove juice method. $1.0 \%$ CHG-AL and $0.5 \%$ CHG-AL exhibited significantly greater efficacy than $0.2 \mathrm{w} / \mathrm{v} \%$ benzalkonium chloride/ethanol preparation immediately and 3 hours after disinfection $(\mathrm{p} \leq 0.05$, Fisher's exact test). The most common microorganisms isolated in this study were coagulase-negative staphylococci (CNS) and Bacillus spp. Immediately after and 3 hours after disinfection with $1.0 \%$ CHG-AL, the counts of CNS were significantly reduced by $180-$ and $170-$ fold, respectively, compared with those seen before disinfection $(\mathrm{p} \leq 0.05$, Student's $t$-test). Immediately after and 3 hours after disinfection with $0.5 \% \mathrm{CHG}-\mathrm{AL}$, the counts of CNS were significantly reduced by $513-$ fold, compared with those detected before disinfection ( $\mathrm{p} \leq 0.05$, Student's $t$-test). Immediately after and 3 hours after disinfection with 1.0\% CHG-AL, the counts of Bacillus spp. were significantly reduced by more than eleven- and seven-fold, compared with those observed before disinfection, respectively, but $0.5 \% \mathrm{CHG}-\mathrm{AL}$ had no effect on the counts of these bacteria. In comparisons between the two timepoints, neither $1.0 \%$ CHG-AL nor $0.5 \%$ CHG-AL exhibited significant $\log _{10}$ reduction factors for the numbers of total microorganisms, CNS, or isolated Bacillus spp., indicating that both disinfectants had strong persistent effects $(\mathrm{p} \leq 0.05$, Student's $t$-test). Therefore, the disinfection efficacy of $1.0 \% \mathrm{CHG}-\mathrm{AL}$ was superior to that of $0.5 \% \mathrm{CHG}-\mathrm{AL}$, based on the significantly more effective action against Bacillus spp.
\end{abstract}

Key words : chlorhexidine gluconate/ethanol preparation (CHG-AL), surgical hand disinfection, persistent effect, Bacillus spp., coagulase-negative staphylococci (CNS) 